\title{
Antonio Gramsci and his Relevance to the Education of Adults ${ }^{1}$
}

\author{
Peter Mayo
}

In his scattered and often cryptic writings appearing as political pamphlets, journalistic pieces, cultural reviews, letters from prison and, most particularly, those notes from the same prison that were intended as the foundation for a comprehensive work für ewig (for eternity), Antonio Gramsci provides elements for a large allembracing educational strategy. This strategy is intended to engender an 'intellectual and moral reform' of a scale that, in his view, would render it the most radical reform since primitive Christianity (Festa, 1976). Educational programmes targeting adults featured prominently in this all-embracing educational strategy. To appreciate the importance of the education of adults in this context, one should highlight some key features of Gramsci's social theory.

\section{Gramsci and Marx}

It is common knowledge that the root of Gramsci's theory is historical materialism. That Gramsci is indebted to Marx's own thought goes without saying, despite the fact that many of Marx's early writings were not accessible to him. After all, Gramsci is credited with having 'reinvented' some of Marx's concepts when discussing important aspects of his native Italy's post-Risorgimento state. One of his more enduring contributions is arguably that of having stressed the cultural dimension of revolutionary practice. He has thus made a significant contribution to various aspects of Marxist theory, including the debate around the 'Base-superstructure' metaphor. At the same time, one must not lose sight of his over-arching political analysis, lest one lapses into cultural reductionism.

Gramsci's works are embedded in a Marxian conception of ideology based on the assumption that 'The ruling ideas are nothing more than the ideal expression of the dominant material relationships, the dominant material relationships grasped as ideas; hence of the relationships which make one class the ruling one, therefore the ideas of its dominance' (Marx \& Engels, 1970, p. 64). Not only does the ruling class produce the ruling ideas, in view of its control over the means of intellectual production (ibid.), but also the dominated classes produce ideas that do not necessarily serve their interests. These classes, that 'lack the means of mental production and are immersed in production relations which they do not control', tend to 'reproduce ideas' that express the dominant material relationships (Larrain, 
1983, p. 24). After all, as Marx and Engels had underlined, '... each new class which puts itself in place of one ruling before it, is compelled, merely in order to carry through its aim, to represent its interest as the common interest of all the members of society, that is expressed in ideal form: it has to give its ideas the form of universality, and represent them as the only rational, universally valid ones' (Marx \& Engels, 1970, pp. 65, 6).

\section{Education and Hegemony}

Although Gramsci did not have access to Die Deutsche Ideologie, from where the above quote is taken, his familiarity with many other works by $\mathrm{Marx}^{2}$ led him to adopt such insights in his theoretical formulations. The above quote illustrates a feature of Hegemony, the term used by Lenin, Plekhanov and others and which also featured in the linguistics writings to which Gramsci, who studied the subject under Matteo Bartoli, had been exposed (Ives, 2004, p. 47). Education is central to his particular formulation of the concept of Hegemony. Hegemony refers to a social situation in which 'all aspects of social reality are dominated by or supportive of a single class' (Livingstone, 1976, p. 235). The emphasis here is on ruling by consent and not simply through force. Gramsci's politics were comprehensive, involving an analysis of class politics in a variety of its forms. As far as education goes, his was a project that extended far beyond an analysis and discussion of schooling and formal educational issues. One might argue that education, in its wider context and conception, played a central role in his overall strategy for social transformation since, in his view, every relationship of hegemony is an educational one (Gramsci, 1975, p. 1331; Gramsci, 1971, p. 350).

His entire political project is therefore an educational project. A process of intellectual and moral reform can only be predicated on such an expansive view of education. Gramsci scholar Joseph A. Buttigieg writes: '.. the role of education in Gramsci's thought cannot be properly appreciated unless one recognizes that it resides at the very core of his concept of hegemony' (Buttigieg, 2002, pp. 69, 70).

\section{The State and Civil Society}

The agencies, which, in his view, engage in this educational relationship, are the ideological social institutions, constituting civil society, such as law, education, mass media, religion etc. Gramsci argues that, in Western society, the State is surrounded and propped up by a network of these institutions that are conceived of as 'a powerful system of fortresses and earthworks' which makes its presence felt whenever the State 'trembles' (Gramsci, 1971, p. 238; Gramsci, 1975, p. 866). As such, social institutions such as schools and other educational establishments are not 'neutral' but serve to cement the existing hegemony, therefore being intimately tied to the interests of the most powerful social groups, especially the bourgeoisie.

Implicit throughout Gramsci's writings on 'the State' and 'Civil Society' is a critique of educational establishments. Contained in his writings are elements for an analysis of the politics of education in the Western capitalist social formation. 
Education is perceived as playing an important role in cementing the existing hegemony. It is crucial in securing consent for the ruling way of life, one that is supportive of and is supported by the prevailing mode of production. Compulsory initial learning, mandated by the Capitalist Italian State, during the years of Fascist rule, is problematised by Gramsci in his critique of the Riforma Gentile and the kind of streaming (tracking) it was intended to bring about. His critique of the Fascist regime's proposed separation between 'classical' and 'vocational' schools strikes me as being well within the radical tradition of opposing any kind of differentiation made on the basis of 'meritocracy' when, in effect, the whole process is one of selection made on the basis of class. Gramsci, however, does not limit himself to criticizing the contemporary reforms but offers alternatives that emerge from his vision of society.

\section{Structure and Agency}

Gramsci was no economic determinist. He was very anti-positivist, a stance that is also reflected in his view of language and linguistics and his criticism, following Bartoli, of the Neogrammarians (Ives, 2004, p. 47). As a matter of fact, his work is generally regarded as having marked a decisive break with the official Marxism of the time (cf. Diskin, 1993, p. 18). A strong sense of agency is conveyed throughout his writings. In an early article, entitled 'La Rivoluzione Contro il Capitale', the young Gramsci argued that the Bolshevik Revolution called into question the canons of historical materialism, a position from which he would move in his more mature years characterized by a deeper understanding of Marx's writings where the canons of historical materialism are not so 'iron like' as the young Gramsci would have us believe. One must bear in mind the particular phase in life in which the pieces by Gramsci that are cited have been written. Nevertheless it would be worth reproducing this quote from a much-cited work (often known in English as 'Against Capital') to capture his enthusiasm for the news of the October Revolution in Russia and to shed light on his earlier reception of Karl Marx's theory:

... facts have overthrown the critical schema within which the history of Russia was supposed to be confined, according to the canons of historical materialism. The Bolsheviks deny Karl Marx, and affirm explicitly by their deeds that the canons of historical materialism are not so ironlike as might be thought, and has been thought ... (the Bolsheviks) are not Marxists, that's all. (Gramsci, cited in Clark, 1977, p. 51; see Italian original in Gramsci, 1997, p. 43)

With respect to Gramsci's anti-positivism, Angelo Broccoli (1972, p. 28) argues that one of the reasons why the young Gramsci was attracted to the works of Benedetto Croce $^{3}$ was simply because the Neapolitan philosopher affirmed human values in the face of the sense of acquiescence and passivity conveyed by Positivism and which Gramsci associated with the mechanistic and deterministic theories of the Second International. As Giuseppe Fiori, arguably Gramsci's best-known biographer, writes, 
For Croce, man [sic] was the unique protagonist of history. His [sic] thought stimulates action-concrete 'ethical-Political' action-which is the creation of new history. (Fiori, 1970, p. 239)

This sense of agency can be discovered in his theoretical formulations concerning Hegemony and the State. For Gramsci, hegemony is characterised by a number of features. It is characterised by its non-static nature (it is constantly open to negotiation and re-negotiation, therefore being renewed and recreated). It is incomplete, selective (Williams, 1976) and there exist moments wherein cracks can be detected. All this indicates that there can be room for counter-hegemonic activity, which can be very effective in specific circumstances. There are also excluded areas of social life that can be explored by people involved in such counter-hegemonic activities.

For Gramsci, the terrain wherein hegemony can be contested is the very terrain which supports it, namely that of Civil Society which is conceived of as a site of struggle. He argued that, because he regarded it as being propped up by the institutions of Civil Society, the State cannot be confronted frontally by those aspiring to overthrow it in order to bring into place a new set of social relationswhat he calls 'a war of manoeuvre'. The process of transforming the State and its coercive apparatus must, to a large extent, precede, rather than follow, the seizure of power (Lawner, 1973, p. 49) through pre-figurative work (Allman, 1988), although this process cannot be fully achieved unless power is finally seized.

Jorge Larrain provides the important caveat that such pre-figurative work can never result in 'total ideological domination' prior to the conquest of the state since, as Gramsci maintains, 'class consciousness cannot be completely modified until the mode of life of the class itself is modified, which entails that the proletariat has become the ruling class' (in Larrain, 1983, p. 82) through 'possession of the apparatus of production and exchange and state power' (my translation from Gramsci, 1997, p. 161). While total ideological domination is not possible prior to the conquest of the state, there is however much work to be carried out beforehand to help generate the climate for change.

\section{War of Position}

People working for social transformation, in Gramsci's case, the proletariat seeking to transform the bourgeois state, had to engage in a 'war of position', a process of wide ranging social organisation and cultural influence. It is through this process that the group creates, together with other groups and sectors of society, an historical bloc, the term borrowed from Georges Sorel that Gramsci uses to describe the complex manner in which classes or their factions are related (Showstack Sassoon, 1982, p. 14):

... every revolution has been preceded by an intense labour of criticism and by the diffusion of culture and the spread of ideas among masses of men [sic] who are at first resistant and think only of solving their own immediate economic and political problems for themselves who have no 
ties of solidarity with others in the same condition. (Gramsci, 1977, p. 12; see original Italian quote in Gramsci, 1967, p. 19)

The primacy of cultural activity for the revolutionary process is therefore affirmed by Gramsci, an idea that reflects the influence of a number people, notably Angelo Tasca. As Clark (1977) has indicated, Gramsci wrote, in Il Grido del Popolo:

Socialism is organization, and not only political and economic organization, but also, especially, organization of knowledge and of will, obtained through cultural activity (p. 53).

\section{The Factory Councils and the Education of Adults}

As a crucial area of 'Civil Society', adult education ${ }^{4}$ was conceived of by Gramsci as having an important role to play in this 'war of position' both at the level of adult education within movements challenging the established state of affairs or at the level of individuals and enclaves operating in and against the state. ${ }^{5}$ Gramsci, very much involved in adult education, as part of his work in the Italian Socialist and subsequently Communist parties, wrote of the existence of altre vie (other routes) when it comes to education and learning. Gramsci saw progressive and emancipatory elements within these altre vie that can complement the kind of Unitarian school he proposed, in Notebooks IV and XII, to advance the interests of the Italian working class. Gramsci's Ordine Nuovo group directed a lot of its energies, during the revolutionary climate which prevailed in Turin, prior to the Fascist take over, towards the Factory Council Movement that was, in effect, an adult education movement through which workers were 'educated' as producers rather than simply as 'wage earners' (Merrington, 1977, p. 158)-salariati (salaried employees) (Gramsci, 1967, p. 261) - and initiated into the process of industrial democracy. ${ }^{6}$ For Gramsci, the Factory Councils were intended to provide the means whereby the proletariat could 'educate itself, gather experience and acquire a responsible awareness of the duties incumbent upon classes that hold the power of the state' (cited in Merrington, 1977, p. 159).

This was to constitute an important step for the working class in the direction of 'exercising leadership before winning Government power' (Gramsci, 1971, p. 57). The emphasis, in these writings, is on the acquisition of industrial democracy, the backbone of the workers' state.

There was to be 'collaboration between manual workers, skilled workers, administrative employees, engineers and technical directors' (Gramsci, 1977, p. 110). Through such collaboration, workers were to experience 'the unity of the industrial process' and see themselves 'as an inseparable part of the whole labour system which is concentrated in the object being manufactured' (ibid.; Italian original in Gramsci, 1967, p. 261). As such, they were to acquire complete mental control over the production process to 'replace management's power in the Factory' (Gramsci, in Mancini, 1973, p. 5). Furthermore, the knowledge acquired at the workplace would, according to Gramsci, lead to a greater understanding of the workings of society: 
At this point the worker has become a producer, for he [sic] has acquired an awareness of his role in the process of production at all levels, from the workshop to the nation to the world. (Gramsci, 1977, p. 111; Italian original in Gramsci, 1967, p. 261)

One assumes that the educational programme which the Factory Councils had to provide, in order to render workers capable of exerting such control, must mirror the spirit of democracy and collaboration it is intended to foster at the workplace and eventually in the envisaged democratic Workers' State (cf. Gramsci, 1977, p. 66). For the kind of environment generated by the Factory Councils was intended to prefigure that of the socialist state (once again, however, we must keep in mind Larrain's important caveat):

The Socialist State already exists potentially in the institutions of social life characteristic of the exploited working class. To link these institutions, co-ordinating and ordering them into a highly centralized hierarchy of competences and powers, while respecting the necessary autonomy and articulation of each, is to create a genuine workers' democracy here and now ... . (Gramsci, 1977, p. 66; see Italian original in Gramsci, 1967, p. 206, 207)

The Factory Council Movement brought Turin, regarded by Gramsci as 'Italy's Petrograd', close to a revolution. The main reason for its ultimate failure was that its activity was not carried out in the context of the alliance called for by Gramsci through his later formulation of the concept of the 'historical bloc'. In retrospect, Gramsci noted that the insurgents, in Turin, were isolated (Adamson, 1980, p. 60). Yet the Factory council was not conceived of by Gramsci as the only agency responsible for the education of adults. In keeping with the idea of a 'war of position', the education of adults involved a cultural offensive on all fronts, across the entire complex of civil society (the term is used by Gramsci in a manner that is very different from the way it is popularly used nowadays).

\section{Different Sites of Adult Learning}

Gramsci's writings convey the idea that different sites of social practice can be transformed into sites of adult learning. As I have argued, his scattered writings reflect a lifelong effort to engage in counter-hegemonic activities in all spheres of social life. Gramsci comes across, in these writings, as an indefatigable organiser and educator who would leave no space unexplored to educate members of the 'subaltern' classes. The area of industrial production becomes an important site of learning. These workplace educational experiences are to be sustained, according to Gramsci, by cultural centres. The Club di Vita Morale, which he helped organise in 1917 and wherein workers read works and gave presentations to each other (De Robbio Anziano, 1987, p. 124), was one such centre. Another centre was the shortlived Institute of Proletarian Culture that drew inspiration from the Russian Proletkult (Gramsci, 1976, p. 216) and the group associated with the French journal 
Clarté that included Romain Rolland (the author who formulated the well known phrase associated with Gramsci and the Ordine Nuovo: pessimism of the intellect, optimism of the will) and Henri Barbusse (Broccoli, 1972, p. 47).

Some of Gramsci's writings reveal a yearning, on his part, for the creation of a cultural association for workers, one that offers space where workers can debate all that is of interest to the working class movement. Gramsci wrote that such an institution 'must have class aims and limits. It must be a proletarian institution seeking definite goals' (Gramsci, 1985, p. 21; Italian original in Gramsci, 1967, p. 91). He also felt that such an association would cater to the need to integrate political and economic activity with an organ of cultural activity (Gramsci, 1985, p. 22). Gramsci might have been inspired, in this respect, by the writings of Anatoli Lunacarskij, who had an article on the issue translated into Italian and published in Il Grido del Popolo. And reference is made, in a piece in L'Ordine Nuovo, to the first experiences of a proletarian school. Gramsci glorifies this institute and its participants, extolling the latter's determination to learn, despite their tiredness after a day's work. And, according to Gramsci, what added to their merit was that they learnt not to simply advance personally, as with the bourgeois schools, but to help realise their dream of a better society (Gramsci, 1967, p. 290). The importance of such circles must have been recognised by Gramsci from the very beginning of his political work. Indeed there is evidence that the young Gramsci had, in 1916, delivered talks to workers' study circles in Turin on a variety of topics, including Marx, the Paris Commune, Romain Rolland and the French Revolution (Buttigieg, 1992, p. 68). His engagement as an adult educator therefore started at an early age during which time he was also greatly involved in journalism (ibid.).

\section{Prison School}

The ongoing commitment by Gramsci to explore opportunities for proletarian adult education is reflected in his efforts, despite obvious physical and external constraints, to help create a prison school (scuola dei confinati) at Ustica (De Robbio Anziano, 1987, p. 125) where he would both teach and learn. His long time friend Piero Sraffa, a professor of economics at Cagliari University and later Cambridge University, also provided help. Sraffa opened an account at a Milan bookstore for books to be forwarded to Gramsci. At this 'school', that Gramsci helped set up with Amadeo Bordiga and others, different courses relating to different levels of study were held (Lawner, 1973, p. 66). In a letter to Sraffa, dated 2 January 1927, Gramsci indicates the different grades into which the school was organised. It catered for people of different backgrounds some of whom were semi-illiterate, even though Gramsci pointed out that they were intellectually well developed. There were two courses in French (lower and superior) and a course in German (Gramsci, 1996, pp. 27, 28). While on the island of Ustica, an island on which he and other detainees were allowed to roam about, Gramsci studied German, Russian, economics and history, as he discloses in a letter to his sister in law, Tatiana Schucht, dated $9^{\text {th }}$ December 1926 (Gramsci, 1996, p. 10). It is to be 
assumed, however, that Gramsci studied some of these subjects on his own, thanks also to the books procured on his behalf by Piero Sraffa.

\section{Periodicals}

This experience as well as the earlier experiences relating to Gramsci's pre-prison life as a 'full time revolutionary' indicates that, for Gramsci, transformative education can take place in a variety of sites of social practice. This strikes me as being well within the tradition of radical, non-formal adult education, particularly the tradition that incorporates the efforts of movements seeking structural change. One can infer from the pre-prison efforts, that the educational activities within the various sites were to be sustained by such media as cultural reviews that Gramsci, no doubt drawing on his own experience as a journalist, must have regarded as important instruments of informal adult education. The Ordine Nuovo was intended as a review of socialist culture and therefore as an important source of adult education. It constituted the means whereby cultural productions of the period were analysed from the standpoint of the 'subaltern' class whose interests the review purported to represent. Such a review must therefore have been intended as an important means of assisting the Turin workers in the important process of critically appropriating elements of the dominant culture. It also served as a means to develop the more emancipatory aspects of popular culture, with a view to creating a new culture reflecting an alternative Weltanschauung.

\section{Adult Educator as Organic Intellectual}

What type of adult educator did Gramsci have in mind? Does agency lie with a potential target-learning group? The agents who, in Gramsci's view, play a pivotal role in this 'war of position' are the organic intellectuals - cultural or educational workers who are experts in legitimation. They emerge 'in response to particular historical developments' (Ransome, 1992, p. 198), as opposed to traditional intellectuals whose 'organic' purpose is over as society enters a different stage of development (ibid.). Adult educators engaging in counter-hegemonic cultural activity are to be conceived of, according to the Gramscian conception, as intellectuals who are organic to the 'subaltern' groups aspiring to power. This implies that they should be politically committed to those they teach. Unless this occurs, there can be no effective learning. One of the reasons why Gramsci did not believe that the Italian 'popular universities' (adult education centres) operated in the interest of the proletariat was that the intellectuals involved were not committed to this class (Broccoli, 1972, p. 41). More care was taken, in these schools, to impress (si bada più alla lustra) than to teach effectively (Gramsci, 1967, p. 36) in a process described by Gramsci as that in which bagfuls of victuals (sporte di vivere) were distributed (Gramsci, 1967, p. 34). Gramsci argued that the working class should produce its own intellectuals or else assimilate traditional intellectuals, the process of assimilation being a crucial aspect of the 'war of position' itself. It is most likely that a social group's endeavours, in this regard, would be characterised by a combination of both processes. 


\section{Educational Needs of Industrial Working Class}

As for the issue of whether there exists, in Gramsci, a social category with whom the responsibility for agency lies, one can argue that, despite his first hand knowledge of the peasant dominated South, it was to the industrial proletariat, located in Turin, that he looked for revolutionary potential. Although he attempted to deal, at some depth, with the Southern Question (cf. Gramsci, 1964, pp. 797-819; Gramsci, 1995; Verdicchio, 1995) and advocated an historical bloc characterised by a 'national-popular' alliance between the proletariat and the peasantry, he ascribed to the former the role of leadership or directorship (direzione) in the alliance:

... we favoured a very realistic and not at all 'magic' formula of the land for the peasants; but we wanted it to be realised inside the framework of the general revolutionary action of the two allied classes under the leadership of the industrial proletariat. (Gramsci, 1957, p. 30; Italian original in Gramsci, 1964, p. 799; Gramsci, 1997, p. 181; my emphasis)

Most of Gramsci's writings, which are relevant to adult education, focus on the educational needs of the industrial working class. The issue of adult literacy, an important concern for anyone dealing with adult education in the Southern Italian regions, where illiteracy was widespread, is given lip service in Gramsci's writings. There is a very short piece that explains the causes of peasant class resistance to compulsory education. It is one of the very few extant pieces by Gramsci on this topic, if not the only piece (Gramsci, 1964, pp. 235-236). In short, Gramsci's writings identify a specific adult education clientele. This can be explained by the fact that these writings are the product of his first hand experience as activist, organiser and adult educator, an experience that was confined to the city of Turin. He therefore wrote specifically about the area in which he was directly involved.

\section{Pedagogy}

There is also something to be said about the kind of pedagogy that ought to be encouraged. That Gramsci was concerned with mitigating hierarchical relations between those who 'educate' and 'direct' and those who learn can be seen from his writings concerning philosophy, language, culture, and hegemony relations. Echoing Marx's Third Thesis on Feuerbach ('the Educator must himself be educated'), he advocates a relationship that has to be 'active and reciprocal', one whereby 'every teacher is always a pupil and every pupil a teacher' (Gramsci, 1971, p. 350). The same applies to his views concerning educators. In his note on the Unitarian School, which led certain authors to argue that he advocated a conservative education (cf. Entwistle, 1979; Senese, 1991), or elements of such an education (De Robbio Anziano, 1987), for working class empowerment, Gramsci refers to the teacher who limits himself or herself to a straightforward transmission of facts as 
'mediocre' (Gramsci, 1971, p. 36; Gramsci, 1975, p. 499). Such a teacher is closely associated with the 'old school' that, according to Gramsci, has its merits. He underlines these merits to move to one extreme in order to expose what he regarded as the shortcomings of the other, in this case, the Gentile Reforms. This school was, nevertheless, considered wayward enough by Gramsci to justify the struggle for its replacement (Gramsci, 1971, p. 36; Gramsci, 1975, p. 499). In fact, as Mario Aligero Manacorda (in Gramsci, 1972, p. xxix) states, the writing on the Unitarian School, highlighting the virtues of the old humanistic school, is an epitaph to this school. It laments the passing of this school that cannot continue to serve its purpose any longer since the social reality has changed. The problem for Gramsci, however, is that the new system that was being introduced for its replacement appeared to him to be a retrograde one, falling far short of his ideal of a fusion between the academic and the technical. The old school, which has to be replaced, has greater merit than the one proposed by Gentile possibly through the influence of his mentor, Benedetto Croce (see Borg \& Mayo, 2002, p. 102).

In his epitaph for the outgoing school, Gramsci highlighted the merits of the conveyance of facts, an aspect of the old school, in reaction to what he perceived to have been the emerging practice of carrying out dialogue in a vacuum. The implication for adult educators seems to be that a certain degree of instruction needs to be imparted to render any dialogical education an informed one. The pedagogy is directive (it is intended towards a political goal), striking a balance between spontaneity and conscious direction-spontaneità and direzione consapevole (Gramsci, 1975, p. 328). Furthermore, the organic intellectual/adult educator is equipped with a body of knowledge and theoretical insight that, nevertheless, needs to be constantly tested and renewed through contact with the learners/ masses. This explains Gramsci's advocacy of a dialectical relationship between adult educators/organic intellectuals and the learners/masses. The reciprocal educational relationship that he advocates and which was cited earlier exists throughout society as a whole and for every individual relative to other individuals. It exists between intellectual and non-intellectual sections of the population (Gramsci, 1971, p. 350).

\section{Cultural Dimension of Workers' Education}

What constitutes 'really useful knowledge' in this context? Quite often, we come across workers' education programmes that are restricted to production issues (e.g. labour studies), irrespective of whether they are narrow 'tool' or broader 'issue' courses. This comprises courses in negotiation theory, economics, labour studies and so forth. Seldom included are areas which cover a wider terrain, including areas that featured prominently in the repressed historical tradition of independent working class education and which provided the basis for the type of cultural studies developed in English adult education. Gramsci advocated a broader education encompassing all those areas of knowledge that constitute a terrain where values are conveyed and subjectivities are shaped. Gramsci focuses, in his writings, on both aspects of the conventional and problematic 'high' and 'low' culture divide. 
Referring to the traditional school, in his writing on the Unitarian School, Gramsci argues that pupils learnt Greek and Latin for no immediate practical reasons but 'to know at first hand the civilization of Greece and Rome-a civilization that was a necessary pre-condition for our modern civilization'. He goes on to say:

In other words, they learnt them to be themselves and know themselves consciously. (Gramsci, 1971, p. 37; Italian original in Gramsci, 1975, p. 1544)

His focus on both aspects of the 'high' and 'low' cultural divide is carried out as part of a constant search for a synthesis between the potentially emancipatory aspects of both. This is done with a view to providing the basis for a proletarian culture. It is perhaps for this reason that he expresses great concern, in the Quaderni, for the way in which areas of popular culture are incorporated by the dominant culture. For this reason, he expresses great interest in works like Dostoyevsky's novel which draws on the serial, and therefore popular, fiction to produce 'artistic' fiction, and, in so doing, it reveals the interplay between the 'popular' and the 'artistic' (Forgacs \& Nowell Smith, 1985, p. 12).

Gramsci considered several elements of the 'canon' to be relevant to the needs of the working class. This could explain the enthusiasm he shows, in some of his reviews, for plays and writings by established figures which contain themes and moral actions that, he felt, resonate with the experiences of members of subordinated social groups. For instance, he seems to have seen in the figure of Ibsen's Nora Helmer, the protagonist in A Doll's House (cf. Gramsci, 1976: pp. 246, 247; Gramsci, 1985, p. 72), the basis for the 'new feminine personality' about which he writes in the notes on 'Americanism and Fordism' (cf. Gramsci, 1971, p. 296; Gramsci, 1975, p. 2149).

The inference that I draw from the foregoing is that such knowledge should feature in a programme of cultural preparation of workers developed on Gramscian lines. This knowledge should not, however, be treated unproblematically. The process involved is one of critical appropriation:

Creating a new culture does not only mean one's own individual 'original' discoveries. It also, and most particularly, means the diffusion in a critical form of truths already discovered, their 'socialisation' as it were, and even making them the basis of vital action, an element of co-ordination and intellectual and moral order. (Gramsci, 1971, p. 325; Italian original in Gramsci, 1997, pp. 1377, 1378)

\section{Language}

The issue of mastering the dominant culture in order to transform it is also developed in other aspects of Gramsci's work. For instance, Gramsci advocates mastery of the dominant language for members of the 'subaltern' classes not to remain on the periphery of political life. ${ }^{7}$ This does not mean that he endorsed the hegemony of this language (the Tuscan dialect so strongly favoured by Manzoni). It constituted, 
after all, a form of 'passive revolution' and did not connect with the various languages of subaltern groups that, as with all languages, reflect specific conceptions of the world. This has implications for adult literacy programmes. Gramsci believed in the importance of a national standard language but he favoured a process of linguistic hegemony characterised by the presence of a normative grammar that derived from the interactions of the spontaneous grammars found in the peninsula's different regions-a national popular standard language, if you will, which would be more democratic in that it would reflect the 'collective will' (see Ives, 2004, p. 100). And organic intellectuals had an important role to play in elaborating and creating connections between these spontaneous grammars, something which was not occurring in Gramsci's time, since those people with potential for intellectual leadership among the subaltern classes were co-opted partly through their being equipped with a normative grammar that was alien to the subordinated classes. This normative grammar, therefore, served to alienate potential organic intellectuals from these subaltern classes, rendering them traditional intellectuals instead-intellectuals whose activity deceptively appeared to be devoid of any social moorings when in actual fact this activity served to consolidate the hegemony of the dominant groups. ${ }^{8}$ In the short piece, dealing with illiteracy, referred to earlier, he emphasises the need for peasants to learn a standard language to transcend their insular environment characterised by campanilismo (parochialism) (Gramsci, 1964, p. 236):

If it is true that every language contains the elements of a conception of the world and of a culture, it could also be true that from anyone's language, one can assess the greater or lesser complexity of his [sic] conception of the world. Someone who only speaks dialect, or understands the standard language incompletely, necessarily has an intuition of the world which is more or less limited and provincial. (Gramsci, 1971, p. 325)

Moreover, he also felt that the proletariat would achieve greater unity through the ability to speak one common language, although he refutes the idea that Esperanto can constitute such a language. This unity would not be achieved if various regional groups, within the subaltern classes, confine themselves to merely speaking their own particular dialect.

\section{Historical Dimension}

For Gramsci, it is not only the dominant culture that has to be mastered in processes of adult education but also knowledge of history. As with the canon, which has its roots in the past, history too needs to be confronted, mastered and transformed. History should be a feature of working class adult education. $\mathrm{He}$ states:

If it is true that universal history is a chain made up of efforts man [sic] has exerted to free himself [sic] from privilege, prejudice and idolatry, then it is hard to understand why the proletariat, which seeks to add 
another link to the chain, should not know how and why and by whom it was preceded or what advantage it might derive from this knowledge ... (Gramsci, 1971, p. 41)

\section{Philosophy of Praxis}

There are, however, other issues, in so far as content is concerned, which are emphasised by Gramsci. The earlier discussion on workplace democracy highlights the importance that Gramsci attached to the workers' sharing of knowledge of the entire production process and of their learning economic and administrative skills. Being first and foremost a Marxist, Gramsci must have considered important a process of education through praxis. In fact, the 'philosophy of praxis' (Gramsci, 1975, p. 1437) was central to his work spanning across the Quaderni. It is Gramsci's overarching philosophy that he contrasts with 'common sense'. Gramsci saw ideas that reflect the dominant material relationships as residing in those areas he identifies with 'common sense' which contains elements of 'good sense' but which is, in effect, a distorted and fragmentary conception of the world. It is, according to Gramsci, a 'philosophy of non philosophers' (Gramsci, 1975, p. 1396). This is 'a conception of the world absorbed uncritically by the various social and cultural environments in which the moral individuality of the average man develops' (literal translation by Carmel Borg from Gramsci, 1975, p. 1396; see Borg \& Mayo, 2002). Gramsci draws connections between popular religion, folklore (a specific body of beliefs, values and norms [Salamini, 1981] that is uncritical, contradictory and ambiguous in content) and common sense (Borg \& Mayo, 2002, p. 91). The challenge, for Gramsci, is to supersede this common sense through a 'philosophy of praxis', the 'conscious expression' of the contradictions that lacerate society' (Larrain, 1979, p. 81). The 'philosophy of praxis' would undergo a process of elaboration similar to that experienced by Lutheranism and Calvinism before it develops into a 'superior culture' (Caruso, 1997, pp. 85, 86) or 'civiltà'.

The 'philosophy of praxis' is that which enables this common sense to be transformed into 'good sense' and which warrants elaboration to provide the underpinning of an intellectual and moral reform. In contrast to the bifurcation advocated by Benedetto Croce (philosophy for intellectuals and religion for the people), the 'philosophy of praxis' is intended to be a philosophy that welds intellectuals and masses together in a historical bloc (Borg \& Mayo, 2002, p. 89). It is intended to be an instrument for the forging of a strong relationship between theory and practice, consciousness and action (Hoare \& Nowell Smith in Gramsci, 1971, p. XIII).

\section{Education and Production}

And the notion of praxis often appears in a manner that suggests an absolute fusion between education and the world of production. It is for this reason that Gramsci revealed a fascination for forms of art that stressed the relationship between human beings and industry. In fact, he reveals an albeit short-lived fascination for the Futurist movement (Gramsci, 1967: pp. 396, 397) for its having 'grasped sharply 
and clearly that our age, the age of big industry, of the large proletarian city and of intense and tumultuous life, was in need of new forms of art, philosophy, behaviour and Language' (Gramsci, 1985, p. 51). It is this preoccupation that led Gramsci to affirm, somewhat idealistically, the virtues of what Marx would have regarded as a 'polytechnical education', arguing for a strong relationship to be forged between education and production, a notion which Marx had specifically developed in the Geneva Resolution of 1866 (Livingstone, 1984, pp. 186, 187):

Having become dominant, the working class wants manual labour and intellectual labour to be joined in the school and thus creates a new educational tradition (Gramsci, 1985, p. 43).

\section{Migration and the question of Multi-ethnic Education}

Some authors dealing with Gramsci's work, notably Verdicchio (1995) and Apitzsch (2002), have raised the issue of migration and multiculturalism with respect to his notes and other writings. There is much in Gramsci's work that can be of relevance to a process of adult education for multi-ethnic solidarity in an age of globalisation characterised by mobility of capital and labour (certainly not on an equal footing) across borders. The concept of 'national popular', so much emphasised by Gramsci, takes on a specific meaning in this context. What is 'national' is often tied to the culture of hegemonic ethnic groups and is related to the whole structure of hegemony. Concepts such as 'national identity', 'national culture' are thus challenged, in societies that are constantly becoming multiethnic, as part of the process of negotiating relations of hegemony within the countries concerned. A progressive adult education project on the lines indicated by Gramsci would contribute to this contestation, challenging, through the development of informed opinion, dominant constructions of the 'national' etc. Furthermore, as Verdicchio (1995, p. 11) so eloquently argues, with respect to his country of origin (he is an Italian scholar from Naples based in the USA), the 'Southern Question' ('Quistione Meridionale', as Gramsci calls it) extends beyond Italy through the presence elsewhere of the Southern Italian migrant diaspora. One can extend this consideration to the South at large to indicate how the 'question' of southern populations extends beyond this part of the world through the Southern diaspora. If one can take liberties with a statement by Verdicchio, one can say that the emigrant from the South is a 'de-contextualized expression of the contradictory process' of state formation in the country of origin. One of the challenges for critical adult education work with migrants, to emerge from this formulation, is that of enabling the migrants to read not only the world they now inhabit as immigrants but also the world they left. As Paulo Freire discovered, with respect to Brazil, the period of migration (exile in his case) presents an opportunity for a critical distancing from the world one once knew to 'relearn' it (a favourite Freire term with respect to Brazil) in a more critical vein (see the discussion in Freire \& Faundez, 1989). The same would apply to critical educators, engaged in Northern countries, working with migrants from the world's southern regions. In this respect, there is relevance, 
for the current situation, in Gramsci's insistence that the industrial proletariat in the North of Italy, which included in large part, immigrants or the offspring of immigrants from the South, must bring the Southern Question to the forefront of the proletariat. In this respect, he maintains that the Turin communists had the undeniable merit of having brought the Southern Question to the attention of the workers' vanguard, identifying it as one of the key issues for the revolutionary proletariat's national politics. (Gramsci, 1997, pp. 181, 182) The Southern Question takes on a larger meaning and significance in this day and age. Furthermore, the national popular alliance of workers and peasants, which Gramsci called for with respect to Italy, takes on a larger more global North-South meaning in this age of mass migration from South to North. Adult education programmes of a truly internationally socialist kind, in northern contexts, must constantly foreground the issue of the South in the interest of generating North-South solidarity and confronting misplaced alliances (this includes the false alliance between 'labour' and 'management' against 'the competition') based on racist, labour market segmentation strategies. Such an anti-racist programme of adult education, allied to strong social action, can only be successful if rooted in political economy and an understanding of a history of colonialism. These are the sorts of elements that Gramsci sought to bring to his analysis of the Southern Question in Italy, with his emphasis on political economy and historical understanding of the Risorgimento and the process of 'internal colonialism' it brought about.

\section{Conclusion: Adult Education for Counter-Hegemonic Action}

To conclude, I would argue that Antonio Gramsci saw in the education and cultural formation of adults the key towards the creation of systematic and effective counter-hegemonic action. The attainment of an intellectual and moral reform entailed a lengthy process of education characterised by what Raymond Williams would call the 'long revolution'. Adult education in its many forms, formal, non-formal and informal, was to play an important role in this process. Organic intellectuals engaged in this lengthy process of working for social transformation were to explore a number of sites with the potential to serve as sites of transformative learning. Gramsci himself stood as a model in this regard with his unstinting efforts at engaging in projects and carving out spaces for adult learning both during his active years in the public domain and during moments of his incarceration. However it is not only to his various projects that adult educators need to turn to gain inspiration but also to the various theoretical insights deriving from his own revolutionary praxis, insights through which Antonio Gramsci has made a tremendous contribution to modern social and educational theory.

\section{Notes}

1. This chapter draws from Mayo, 1999.

2. In volume IV of his edited critical edition of the Quaderni del Carcere, Valentino Gerratana provides the list of texts by Marx and Engels that Gramsci cites in the Notebooks. These 
include Capital, the Theses on Feuerbach, the Contribution to the Critique of Hegel's Philosophy of Right (Introduction), The Holy Family, The Eighteenth Brumaire of Louis Napoleon, Critique of the Gotha Programme, besides numerous letters and articles (Gerratana in Gramsci, 1975, pp. 3062, 3063).

3. For a recent study on Croce see Rizi, 2003.

4. For a comprehensive overview of the way Gramsci's ideas have been taken up in adult education see Borg, Buttigieg and Mayo (2002).

5. For a recent empirical piece concerning the work of an adult education organization operating in and against the State see Mayo, 2005.

6. For an empirical study that derives inspiration from Gramsci's factory council work, see Livingstone (2002).

7. For an excellent text on language in Gramsci's writings, see Ives, 2004.

8. This section owes a lot to the rich discussion on the subject of 'Language and Hegemony in the Prison Notebooks' in Ives, 2004, Chapter 3.

\section{References}

Adamson, W. (1980) Hegemony and Revolution (Berkeley, CA, \& London, University of California Press).

Allman, P. (1988) Gramsci, Freire and Illich: Their contributions to education for socialism, in: T. Lovett (ed.), Radical Approaches to Adult Education. A reader (London, Routledge).

Apitzsch, U. (2002) Gramsci and the Current Debate on Multicultural Education, in: C. Borg, J. Buttigieg, and P. Mayo (eds), Gramsci and Education (Lanham, MD, Rowman \& Littlefield).

Borg, C. \& Mayo, P. (2002) Gramsci and the Unitarian School. Paradoxes and Possibilities, in: C. Borg, J. Buttigieg, and P. Mayo (eds), Gramsci and Education (Lanham, MD, Rowman \& Littlefield).

Borg, C., Buttigieg, J. \& Mayo, P. (2002) Introduction. Gramsci and Education. A Holistic Approach, in: C. Borg, J. Buttigieg, and P. Mayo (eds), Gramsci and Education (Lanham, MD, Rowman \& Littlefield).

Broccoli, A. (1972) Antonio Gramsci e l'educazione come egemonia (Firenze, La Nuova Italia).

Buttigieg, J. A. (2002) On Gramsci, Daedalus, Summer, pp. 67-70.

Clark, M. (1977) Antonio Gramsci and the Revolution that Failed (New Haven \& London, Yale University Press).

Caruso, S. (1997) La riforma intellettuale e morale, in: Gramsci: I Quaderni del Carcere. Una riflessione politica incompiuta, ed. S. Mastellone (Turin, UTET Libreria).

De Robbio Anziano, I. (1987) Antonio Gramsci e la Pedagogia del Impegno (Naples, Ferraro).

Diskin, J. (1993) Gramsci in Rethinking Marxism, International Gramsci Society Newsletter, 2, pp. $18-20$.

Entwistle, H. (1979) Antonio Gramsci-Conservative Schooling for Radical Politics (London, Routledge and Kegan Paul).

Festa, S. (1976) Gramsci (Assisi, Cittadella Editrice).

Fiori, G. (1970) Antonio Gramsci: Life of a revolutionary (London, New Left Books).

Forgacs, D. \& Nowell Smith, G. (eds) (1985) Antonio Gramsci, Selections from Cultural Writings. (Cambridge, MA, Harvard University Press).

Freire, P. and Faundez, A. (1989) Learning to Question. Pedagogy of liberation (Geneva, World Council of Churches).

Gramsci, A. (1957) The Modern Prince and Other Writings, L. Marks (ed.) (New York, International Publishers).

Gramsci, A. (1964) 2000 Pagine di Gramsci, Vol. 1, G. Ferrara \& N. Gallo (eds) (Milan, Il Saggiatore).

Gramsci, A. (1967) Scritti Politici 1 (Roma, Editori Riuniti). 
Gramsci, A. (1971) Selections from the Prison Notebooks, Q. Hoare \& G. Nowell Smith (eds) (New York, International Publishers).

Gramsci, A. (1972) L'Alternativa Pedagogica, M. A. Manacorda (ed.) (Firenze, La Nuova Italia). Gramsci, A. (1975) Quaderni del Carcere, Edizione Critica, V. Gerratana (ed.) (Turin, Einaudi). Gramsci, A. (1976) Scritti 1915-1921, S. Caprioglio (ed.) (Milan, Mozzi Editore).

Gramsci, A. (1977) Antonio Gramsci, Selections from Political writings (1910-1920), Q. Hoare \& J. Matthews (eds) (New York, International Publishers).

Gramsci, A. (1985) Antonio Gramsci, Selections from Cultural Writings, D. Forgacs \& G. Nowell Smith (eds) (Cambridge, MA, Harvard University Press).

Gramsci, A. (1995) The Southern Question, P. Verdicchio (trans. and ed.) (Lafayette, IN, Bordighera Inc).

Gramsci, A. (1996) Lettere dal Carcere (two volumes), A. Santucci (ed.) (Palermo, Sellerio).

Gramsci, A. (1997) Le Opere. La Prima Antologia di Tutti Gli Scritti, A. Santucci (ed.) (Rome, Editori Riuniti).

Ives, P. (2004) Language and Hegemony in Gramsci (London, Pluto Press; Halifax N.S., Fernwood Publishing).

Larrain, J. (1979) The Concept of Ideology (London, Hutchinson).

Larrain, J. (1983) Marxism and Ideology (Atlantic Highlands, NJ, Humanities Press).

Lawner, L. (ed.) (1973) Letters from Prison, Antonio Gramsci (New York, The Noonday Press).

Livingstone, D. W. (1976) On Hegemony in Corporate Capitalist States: Materialist structures, ideological forms, class consciousness and hegemonic acts, Sociological Inquiry, 46:3, pp. 235-250.

Livingstone, D. W. (1984) Class, Ideologies and Educational Futures (Sussex, The Falmer Press).

Livingstone, D. W. (2002) Working Class Learning, Cultural Transformation, and Democratic Political Education: Gramsci’s legacy, in: C. Borg, J. Buttigieg, and P. Mayo (eds), Gramsci and Education (Lanham, MD, Rowman \& Littlefield).

Mancini, F. (1973) Worker Democracy and Political Party in Gramsci's Thinking. Occasional paper. (Bologna, School of Advanced International Studies, The Johns Hopkins University).

Marx, K. \& Engels, F. (1970) The German Ideology, C. J. Arthur (ed.) (London, Lawrence and Wishart).

Mayo, P. (1999) Gramsci, Freire and Adult Education. Possibilities for transformative education (London, Zed Books).

Mayo, P. (2005) In and Against the State. Gramsci, war of position and adult education, fournal of Critical Education Policy Studies, 3:2, available at: http://www.jceps.com/ index.php?pageID=article\&articleID=49 (accessed 28 January 2006).

Merrington, J. (1977) Theory and Practice in Gramsci's Marxism, in G. S. Jones (ed.), Western Marxism. A critical reader (London, Verso).

Salamini, L. (1981) The Sociology of Political Praxis-An Introduction to Gramsci's Theory (London, Routledge \& Kegan Paul).

Ransome, P. (1992) Antonio Gramsci, A New Introduction (London, Harvester/Wheatsheaf).

Rizi, F. F. (2003) Benedetto Croce and Italian Fascism (Toronto, University of Toronto Press).

Senese, G. B. (1991) Warnings on Resistance and the Language of Possibility: Gramsci and a pedagogy from the surreal, Educational Theory, 41:1, pp. 13-22.

Showstack Sassoon, A. (ed.) (1982) Approaches to Gramsci (London, Writers and Readers Publishing Cooperative Society).

Verdicchio, P. (1995) Introduction, in: A. Gramsci, The Southern Question (trans. P. Verdicchio) (West Lafayette, IN, Bordighera Inc.).

Williams, R. (1976) Base and Superstructure in Marxist Cultural Theory, in: R. Dale, G. Esland and M. Macdonald (eds), Schooling and Capitalism (London, Routledge and Kegan Paul). 